\title{
Differentiation Increases Type II Calmodulin-Dependent Protein Kinase in the Neuroblastoma/Glioma Cell Line 108CC15 (NG 108-15)
}

\author{
Mary Lou Vallano and Carol M. Beaman-Hall \\ Department of Pharmacology, State University of New York, Health Science Center at Syracuse, Syracuse, New York \\ 13210
}

\begin{abstract}
A type II calcium/calmodulin-dependent protein kinase (CaM kinase II) was purified approximately 300 -fold from cultured neuroblastoma/glioma (NG108) cell homogenate. The purification of the kinase, which used a combination of differential centrifugation and chromatography on cation-exchange, calmodulin-affinity, and gel-filtration resins, was monitored by the ability of the kinase to phosphorylate the high-molecular-weight microtubule-associated protein 2 (MAP-2). The kinase was compared with authentic CaM kinase II purified from rat brain cytosol. Based upon holoenzyme molecular weight, subunit composition and molecular weight, calcium-dependent calmodulin-binding to subunits, calcium/calmodulin-dependent autophosphorylation of subunits, substrate specificity, apparent $k_{m}$ 's for ATP and calmodulin, phosphopeptide maps of subunits, time course, and heat lability, the kinase was identified as a type II calcium/calmodulin-dependent protein kinase. When cellular differentiation was induced under specific conditions of cell culture, a significant increase in the apparent activity and amount of the kinase per $\mathrm{mg}$ protein was observed relative to control cells. These studies suggest that there is an increase in CaM kinase II expression during cellular differentiation, which may relate to the concurrent development of electrical excitability, synaptogenesis, and elaboration of cytoskeletal elements. Thus, the NG108 cell should provide a useful model to study the physiological functions of CaM kinase II.
\end{abstract}

A type II calcium/calmodulin-dependent protein kinase (CaM kinase II) has been purified and biochemically characterized from rat (Fukunaga et al., 1982; Bennett et al., 1983; Goldenring et al., 1983; McGuinness et al., 1983; Yamauchi and Fujisawa, 1983; Schulman, 1984) and mouse (Vallano, 1988) brain cytosol. Cortical and subcortical regions are enriched for $\mathrm{CaM}$ kinase II activity, whereas relatively low levels are present in cerebellum, spinal cord, and pons/medulla (Walaas et al., 1983; Erondu and Kennedy, 1985; Vallano, 1988). These enzymeenrichment measurements are paralleled by immunocytochem-

\footnotetext{
Received Dec. 30, 1987; revised May 12, 1988; accepted July 15, 1988.

We would like to thank James L. Gorecki for excellent technical assistance and the laboratories of Drs. Richard D. Veenstra and Jose Jalife for electrophysiological recording studics. This research was supported by a grant from the National Science Foundation (DCB-\#8602617).

Correspondence should be addressed to Mary Lou Vallano, Ph.D., Department of Pharmacology, SUNY/Health Science Center, 766 Irving Avenue, Syracuse, NY 13210.

Copyright (c) 1989 Society for Neuroscience $0270-6474 / 89 / 020539-09 \$ 02.00 / 0$
}

ical localization studies, which also show that CaM kinase II is present in neuronal somata and dendrites (Ouimet et al., 1984). The holoenzyme has a molecular mass of $500-730 \mathrm{kDa}$ and contains 2 subunits of 50 and $58-60 \mathrm{kDa}$. Both subunits bind calmodulin and ATP and demonstrate calcium/calmodulin-dependent autophosphorylation. The primary structures of the 50 $\mathrm{kDa}$ (Hanley et al., 1987; Lin et al., 1987) and 58-60 kDa subunits (Bennett and Kennedy, 1987) have recently been determined by molecular cloning and potential ATP and calmodulin-binding sites identified. CaM kinase II has been distinguished from other calcium/calmodulin-dependent kinases also present in brain due to its broad substrate specificity and relative abundance.

CaM kinase II has been implicated in a variety of cellular events that utilize calcium as a second messenger, such as excitation/secretion coupling, neurotransmitter biosynthesis, and cytoskeletal function (for reviews, see Nairn et al., 1985; Goldenring et al., 1986). Some of these effects are presumably mediated by calmodulin-dependent phosphorylation of the synaptic vesicle-associated protein, synapsin I; the high-molecularweight microtubule-associated protein, MAP-2; and tyrosine hydroxylase. Additionally, there is now compelling evidence that autophosphorylation of specific sites on CaM kinase II switches it to a calcium/calmodulin-independent state (Lai et al., 1986; Miller and Kennedy, 1986; Schworer et al., 1986), which may prolong the activity of the enzyme after intracellular calcium has been restored to resting levels. A calcium/calmodulin-dependent kinase activity is present in postsynaptic density (PSD) (Carlin et al., 1981; Grab et al., 1981), and the $50 \mathrm{kDa}$ subunit of CaM kinase II has been identified as the major PSD protein (Kennedy et al., 1983; Goldenring et al., 1984; Kelly et al., 1984). These data, in conjunction with earlier studies demonstrating alterations in the amount of major PSD protein with various learning paradigms (Guldner and Ingham, 1979; Vrensen and Cardozo, 1981), suggest that CaM kinase II may play an important role in synaptic plasticity (Siekevitz, 1985; Vallano et al., 1986). As a consequence, investigators are interested in developing model systems to further investigate the cellular functions of CaM kinase II.

The neuroblastoma/glioma cell $(108 \mathrm{CC} 15$, also designated NG108-15) may provide a useful model to elucidate the physiological functions of CaM kinase II in neurons. The cells were originally derived by fusion and culture of a mouse neuroblastoma with a rat glioma (Minna et al., 1972; Amano et al., 1974). The resultant hybrid cells display a variety of neuronal properties that are unique or more strongly expressed compared with either parental cell line, with the additional advantage that they 
are a relatively homogeneous population of self-propagating cells (for review, see Hamprecht, 1977). Under specific conditions of culture, the cells undergo a "differentiation" process characterized by elaboration of numerous cytoskeleton-filled neurites, ability to form functional synapses, and development of electrical excitability. Chronic exposure of cells to dibutyryl cAMP or prostaglandin $\mathrm{E}_{1}\left(\mathrm{PGE}_{1}\right)$ plus theophylline are the most commonly used treatments to induce cellular differentiation (for reviews, see Nirenberg et al., 1983; Hamprecht et al., 1985).

NG108 cells in the differentiated state have been shown to contain receptors for a variety of neuropeptides and other cellsurface active ligands and demonstrate depolarization-dependent release of ACh (for review, see Hamprecht et al., 1985), thus proving useful in investigating the molecular mechanisms of cellular signal transduction. For example, intracellular cAMP (Sabol and Nirenberg, 1979; Charness et al., 1986) and polyphosphatidylinositides (Higashida and Brown, 1986) mediate some of the cellular responses to neurohormones and other agents. However, information regarding the presence and possible function of calcium/calmodulin-regulated kinases in these cells is lacking.

Since at least 4 distinct calcium/calmodulin-dependent protein kinases have been identified in rat brain, the primary objective of the present study was to determine whether CaM kinase II is present in NG108 cells. In addition, studies to examine the possibility that its activity and amount is altered with cellular differentiation were undertaken. An account of this research has been published in abstract form (Vallano and Beaman-Hall, 1987).

\section{Materials and Methods}

Materials. The cells used in this study were the clonal cell line of $108 \mathrm{CC} 15$ (NG108-15), derived by fusion of 6-thioguanine-resistant mouse neuroblastoma cells and bromodeoxyuridine-resistant rat glioma cells (Minna et al., 1972; Amano et al., 1974), generously provided by Dr. Mark Rasenick (Department of Physiology, University of Illinois College of Medicine, Chicago). Cells were cultured in Dulbecco's modified Eagle's media (DMEM) containing $4.5 \mathrm{gm} /$ liter $d$-glucose (Gibco, Grand Island, NY \#430-2100EB). Characterized fetal bovine serum (FBS) was obtained through Hyclone (Logan, UT). Histone (Type VIII-S from calf thymus), Phosphorylase b (EC 2.4.1.1 from rabbit muscle), casein, Staphylococcus aureus V8 protease (EC 3.4.21.19), hypoxanthine, aminopterin, thymidine, dibutyryl cAMP, insulin, transferrin, putrescine dihydrochloride, sodium selenitc, progesterone, cytosinc arabinoside, and molecular-weight standards for gel electrophoresis were obtained from Sigma (St. Louis). Plastic culture flasks were purchased from Falcon (Oxnard, CA). Either PRIMARIA $(60 \mathrm{~mm})$ or INTEGRID $(150 \mathrm{~mm})$ plates from Falcon were used for differentiation studies. $\gamma^{32} \mathrm{P}$-ATP (5$10 \mathrm{Ci} / \mathrm{mmol} ; 1 \mathrm{Ci}=37 \mathrm{GBq}$ ) was purchased from New England Nuclear (Boston). ${ }^{125} \mathrm{I}$-calmodulin $(90 \mathrm{mCi} / \mathrm{mg}$ ) and ACS scintillation cocktail were purchased from Amersham (Arlington Heights, IL). Affi-Gel phenothiazine, affi-gel calmodulin, and Zeta-Probe blotting membranes were purchased from Bio-Rad Laboratories (Richmond, CA). Molecularweight standards for gel filtration, S-Sepharose and Sephacryl S-300 superfine resins, were obtained from Pharmacia (Piscataway, NJ). All other chemicals used in the experiments were reagent grade and were obtained from commercial sources.

Cell culture. The cells were cultured in 75 or $175 \mathrm{~cm}^{2}$ plastic flasks containing 13 or $20-35 \mathrm{ml}$ DMEM media supplemented with $10 \%$ FBS, $0.1 \mathrm{~mm}$ hypoxanthine, $1 \mu \mathrm{M}$ aminopterin, $16 \mu \mathrm{M}$ thymidine (HAT) without antibiotics essentially as described by Hamprecht et al. (1985). Cells were maintained at $37^{\circ} \mathrm{C}$ in a humidified atmosphere of $10 \% \mathrm{CO}_{2}$ and $90 \%$ air in the logarithmic stage of growth, and the medium was changed every $2-3 \mathrm{~d}$ as needed. The cultures displayed a doubling time of $1-2 \mathrm{~d}$. Cell viability was approximately $99 \%$ as assessed by dye exclusion using Nigrosin (Kaltenbach et al., 1958).

In some experiments, cells from these stock cultures were used to seed monolayer cultures of differentiated cells by the addition of di- butyryl cAMP as described by Hamprecht et al. (1985). In some cases nondividing cells were selected by inclusion of $10 \mu \mathrm{M}$ cytosine arabinoside in the culture medium during initiation of cell differentiation. Cells were used 6-9 d after treatment with dibutyryl cAMP. At this stage, the cells demonstrated distinct morphological changes compared with control cells, the most dramatic being elaboration of several long neurites/ cell (results not shown). The development of electrical excitability by the differentiated cells was also documented by conventional microelectrode and whole-cell patch-recording tcchniques (results not shown).

Purification of CaM kinase II. Cells in each flask were harvested following gentle trypsinization $(0.005 \% \mathrm{wt} / \mathrm{vol})$ and centrifuged at 490 $\times g$ for 6 min. The cell pellet was resuspended and washed twice in 10 $\mathrm{ml}$ of buffer A $(50 \mathrm{~mm}$ Tris, $10 \mathrm{~mm}$ EGTA, $10 \mathrm{~mm}$ EDTA, $2 \mathrm{~mm}$ 2-mercaptoethanol, $0.32 \mathrm{~mm}$ phenylmethylsulfonyl fluoride, $\mathrm{pH} 7.2$ ) and resuspended in a final volume of $1 \mathrm{ml}$ buffer $\mathrm{A}\left(1 \times 10^{7}-5 \times 10^{7}\right.$ cells). All subsequent steps were performed at $4^{\circ} \mathrm{C}$. The cells were homogenized by 10 up and down strokes in a Teflon/glass homogenizer at $8000 \mathrm{rpm}$. (Homogenization conditions were optimized by testing different aliquots of cells under different homogenization conditions followed by microscopic examination of the resultant homogenate so that all cells were disrupted following homogenization.) The homogenate was centrifuged at $100,000 \times g$ for $30 \mathrm{~min}$ and the supernatant (cytosol) collected and applicd to S-Scpharose resin at a protein concentration of $2-4 \mathrm{mg} / \mathrm{ml}$. The resin had been pre-equilibrated with 50 mM Tris buffer (column bed size, i.d. $1.8 \mathrm{~cm} \times 4 \mathrm{~cm}$; flow rate, $3.5 \mathrm{ml} /$ min). Elution of bound protein was achieved by 2 sequential step gradients of $50 \mathrm{~mm}$ Tris buffer containing $150 \mathrm{~mm} \mathrm{NaCl}$ and $350 \mathrm{~mm} \mathrm{NaCl}$, respectively. The fractions from the Sepharose column containing the majority of recovered enzyme activity were pooled and made $200 \mathrm{~mm}$ $\mathrm{NaCl}, 2 \mathrm{mM} \mathrm{CaCl}_{2}, 10 \%$ glycerol, and applied to a calmodulin-affinity resin that had been equilibrated with $50 \mathrm{~mm}$ Tris buffer, $200 \mathrm{~mm} \mathrm{NaCl}$, $2 \mathrm{mM} \mathrm{CaCl}_{2}, 10 \%$ glycerol (column bed size, i.d. $1.0 \mathrm{~cm} \times 4.5 \mathrm{~cm}$; flow rate, $0.4 \mathrm{ml} / \mathrm{min}$ ). The calmodulin-binding proteins were eluted from the column as a sharp peak after substituting 2 mм EGTA for 2 mм calcium in the buffer. The peak fractions containing the majority of calmodulin-dependent kinase activity were applied to a calibrated column of Scphacryl S-300 supcrfinc resin that had been equilibrated with $50 \mathrm{~mm}$ Tris, $150 \mathrm{~mm} \mathrm{NaCl}, 1 \mathrm{~mm} \mathrm{MgCl}$ (column bed size, i.d. $1.5 \mathrm{~cm}$ $\times 90 \mathrm{~cm}$; flow rate, $0.32 \mathrm{ml} / \mathrm{min}$ ). The putative kinase from NG108 cells was compared with authentic CaM kinase II purified from rat brain cytosol essentially as described by Goldenring et al. (1983).

Phosphorylation assay. Calcium/calmodulin-dependent kinase activity was measured with a standard phosphorylation assay in the presence or absence of $0.1 \mathrm{~mm}$ trifluoperazine (TFP) as previously described (Goldenring et al., 1983; Vallano et al., 1985). For quantitation of enzyme specific activity and recovery throughout the purification protocol, samples were incubated for $30 \mathrm{sec}$ at $30^{\circ} \mathrm{C}$ using exogenous MAP-2 as a substrate under linear rate conditions (final volume, $100 \mu l$ ). For quantitation of enzyme activity in individual fractions during chromatography on cation-exchange resin, calmodulin-affinity resin and gelfiltration resin, samples were incubated for $30 \mathrm{sec}$ at $30^{\circ} \mathrm{C}$ using endogenous autophosphorylation of the 50 and 58-60 kDa subunits as a measure of activity. The reaction was terminated by addition of $50 \mu \mathrm{l}$ of a stop solution containing $0.5 \mathrm{~m}$ sucrose, $2.5 \% \mathrm{SDS}, 25.0$ пnм EDTA, and a trace amount of pyronin $Y$. Samples were heated at $90^{\circ} \mathrm{C}$ for $2-$ $3 \mathrm{~min}$ and cooled, and $11 \%$ (vol/vol) 2-mercaptoethanol was added.

Proteins were resolved on SDS-PAGE using 7 or $8 \%$ acrylamide gels $(12 \mathrm{~cm})$ and 4 or $5 \%$ stacking gels $(2 \mathrm{~cm})$, respectively, according to the method of Laemmli (1970). Where indicated, protein was also resolved on a mini-gel system (Bio-Rad). The acrylamide/bis acrylamide ratio was $30 \%: 0.8 \%$. After electrophoresis for $1-3 \mathrm{hr}$ at constant current $(50$ $\mathrm{mA} / \mathrm{gel}$ ), gels were stained with Coomassie blue or silver reagent (Merril et al., 1981), destained, and dried on filter paper, followed by autoradiography on Kodak XAR film. The specific activity and recovery of kinase was assessed by excision of specific proteins from SDS-PAGE, solubilization of the gel slice in $300 \mu \mathrm{l}$ of $30 \%$ hydrogen peroxide for $10-12 \mathrm{hr}$ at $60^{\circ} \mathrm{C}$, and scintillation spectroscopy in $10 \mathrm{ml}$ of scintillation cocktail. In some experiments, quantitation of kinase activity was verified by densitometry of gels and autoradiograms using a Shimadzu CS930 densitometer with automatic integration capacity.

Phosphopeptide mapping. Using l-dimensional peptide mapping, the putative CaM kinase II subunits from NG108 cells were compared with authentic CaM kinase II subunits that had been purified from rat brain. Purified kinase from NG108 cells or rat brain cytosol was phosphorylated in the standard assay system and subsequently resolved on SDS- 
PAGE (8\% resolving gel). The autophosphorylated subunits were excised from the gel, applied to a second SDS-PAGE (3.7\% stacking gel/ $15 \%$ resolving gel) and subjected to limited proteolysis for $2 \mathrm{hr}$ in the stacking gel using $10 \mu \mathrm{g} \mathrm{S}$. aureus V8 protease according to the method of Cleveland et al. (1977). The phosphopeptides were subsequently visualized by autoradiography

Substrate specificity studies. Calmodulin=dependent kinase II activity was measured with the standard phosphorylation assay in the presence of the following exogenous substrates (final concentrations): MAP-2 (0.3 $\mathrm{mg} / \mathrm{ml})$, tubulin $(0.1 \mathrm{mg} / \mathrm{ml})$, histone $(0.1 \mathrm{mg} / \mathrm{ml})$, phosphorylase $b(0.5$ $\mathrm{mg} / \mathrm{ml})$, and casein $(0.5 \mathrm{mg} / \mathrm{ml})$. These concentrations were selected in order to compare them with previous studies performed with rat brain kinase (Bennett et al., 1983; Goldenring et al., 1983). The rate of calmodulin-dependent kinase activity was linear over the range of concentrations used in the experiments (10-90 ng; results not shown).

Calmodulin-binding. Calmodulin-binding was assessed by electrophoresing protein from SDS-PAGE to Zeta-Probe blotting membrane (Western blotting), followed by incubating the Zeta-Probe membrane first with $5 \%$ nonfat dry milk to reduce nonspecific binding and then with ${ }^{125} \mathrm{I}$-calmodulin $(1 \mu \mathrm{Ci} / \mathrm{blot})$. Specific binding of calmodulin to protein was visualized by autoradiography. This procedure is essentially as described by Gorelick et al. (1983) with the modifications of Peluso and Rosenberg (1987). Complete transfer of sample protein from SDSPAGE to blotting membranes was verified by the absence of detectable protein when the gel after transfer was stained with Coomassie blue. The calcium dependence of ${ }^{125} I$-calmodulin-binding was evaluated in the presence and absence of EGTA in the buffer used to wash the blot.

Tubulin and MAP-2 preparation. Sheep brain microtubules were prepared by temperature-dependent polymerization/depolymerization as originally described by Shelanski et al. (1973) and modified by Vallano et al. (1985). MAP-2 was partially purified from microtubules by heat treatment and clarified by centrifugation according to the method of Fellous et al. (1977). The heat-stable MAP proteins in the supernatant were subsequently dialyzed overnight against 3 changes of $10 \mathrm{~mm}$ $2-(N$-morpholino) ethane sulfonic acid (Mes) buffer, $\mathrm{pH} 6.8$, and used at a concentration of $0.3 \mathrm{mg} / \mathrm{ml}$. Based upon SDS-PAGE, isoelectric focusing, and scanning densitometry, the preparation contained primarily MAP-2 and the tau proteins. The preparation did not demonstrate calmodulin-dependent kinase activity when tested in the standard phosphorylation assay, indicating that endogenous CaM kinase II was inactivated during heat treatment.

In some studies, tubulin was tested as a substrate for the calmodulindependent kinase. Twice-cycled microtubules containing approximately $85 \%$ tubulin were prepared from rat brain cytosol as described by Vallano et al. (1985). Tubulin was further purified by chromatography of the microtubule preparation on phosphocellulose resin using the method of Weingarten et al. (1975). Based upon SDS-PAGE, isoelectric focusing and scanning densitometry, the phosphocellulose-purified preparation contained greater than $95 \%$ alpha and beta tubulin.

Other procedures. Unlabeled calmodulin was purified from calf brain by chromatography on DEAE-cellulose and Affi-Gel phenothiazine as described by Marshak et al. (1981). Isoelectric focusing was performed using an Ephortec isoelectric focusing cell (Haake Buchler, Saddle Brook, $\mathrm{NJ}$ ) using a $\mathrm{pH}$ gradient of 3-10. Protein was determined by the method of Bradford (1976) using BSA as a standard.

\section{Results}

\section{Purification of calmodulin-dependent kinase activity}

Initial experiments employed a standard phosphorylation assay for endogenous calmodulin-dependent kinase activity in wholecell homogenates, and in soluble and particulate fractions derived from high-speed centrifugation of homogenates. Since calmodulin is endogenous to cells, the assay employed trifluoperazine-inhibitable kinase activity as a measure of calmodulindependent activity. These preliminary experiments suggested the presence of a calmodulin-dependent kinase activity in NG108 cells (results not shown). In most experiments, $40-60 \%$ of the total kinase activity was recovered in the soluble fraction, whereas the particulate fraction contained the remainder of the kinase activity. Typically, the calmodulin-dependent kinase activity in the high-speed supernatant plus the particulate fraction was 30\%

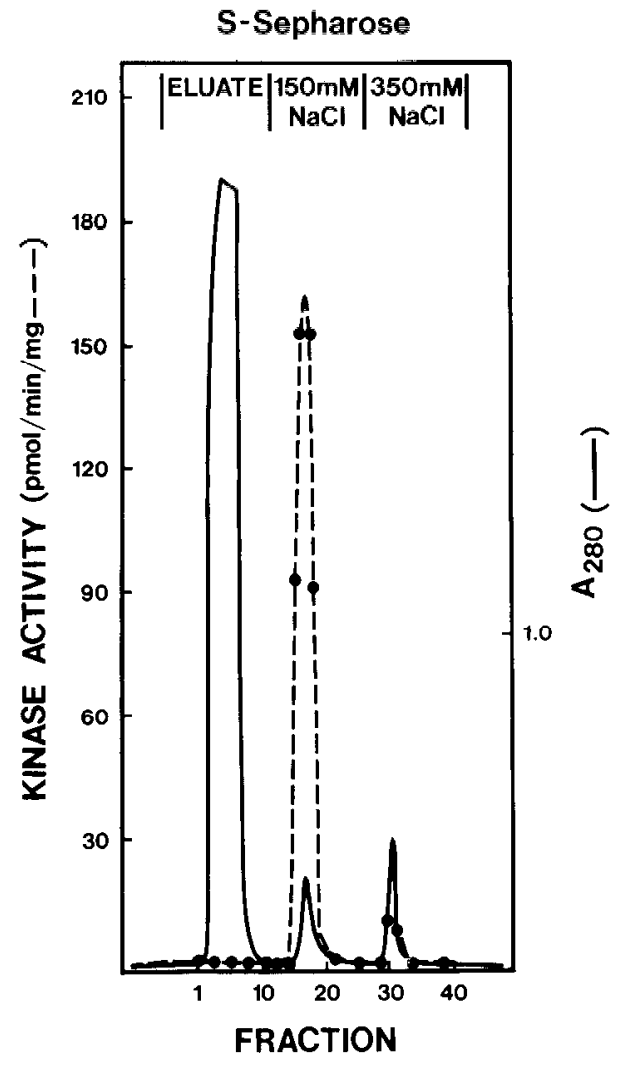

Figure 1. S-Sepharose elution profile of calcium/calmodulin-dependent kinase activity. Approximately $16 \mathrm{ml}$ of cytosol $(2-4 \mathrm{mg} / \mathrm{ml})$ was chromatographed on S-Sepharose cation-exchange resin under the conditions described in Materials and Methods. Protein absorbance was monitored at $280 \mathrm{~nm}(\longrightarrow)$ and selected samples were assayed for endogenous calcium/calmodulin-dependent kinase activity (-- ). In the assay to quantitate specific activity and recovery of the enzyme, samples were incubated at $30^{\circ} \mathrm{C}$ for $30 \mathrm{sec}$ using exogenous MAP-2 as substrate (Table 1). Protein was resolved on SDS-PAGE ( $7 \%$ resolving gel), and kinase activity was quantitated by excision of MAP-2 or kinase subunits from the gel followed by scintillation spectroscopy. Calmodulin-independent activity was assessed in the presence of $0.1 \mathrm{~mm}$ trifluoperazine (TFP) and was subtracted from total activity.

greater than the activity assayed in whole-cell homogenate. A degree of uncertainty in the measurement of MAP-2 kinase activity in crude brain homogenate and cytosol has also been observed by other laboratories (Schulman, 1984) and may be due to kinase inhibitors and phosphatases present in these fractions. The soluble fraction, designated as the high-speed supernatant or cytosol, was employed for subsequent purification and characterization of the enzyme.

$S$-Sepharose chromatography. The cytosolic protein was chromatographed on S-Sepharose cation-exchange resin. Bound protein was eluted with 2 sequential step gradients of buffer containing 150 and $350 \mathrm{~mm} \mathrm{NaCl}$, respectively. Figure 1 depicts the protein elution profile (solid lines) and corresponding calmodulin-dependent kinase activity (dashed lines) in selected fractions. The major protein peaks are designated in order of elution at the top of the figure. They consisted of an eluate fraction containing the majority of applied protein that did not bind to the resin (Eluate); a protein peak that was eluted in the presence of $150 \mathrm{~mm} \mathrm{NaCl}(150)$; and a third peak that was eluted in the presence of $350 \mathrm{~mm} \mathrm{NaCl}$ (350). Typically, $35-40 \%$ of the calmodulin-dependent kinase activity in cytosol was 


\section{PROTEIN}

Figure 2. Comparison of endogenous calcium/calmodulin-dependent phosphorylation of cytosolic protein chromatographed on S-Sepharose. Samples containing equal amounts of protein from the 3 major peaks obtained during S-Sepharose chromatography were assayed for endogenous calcium/calmodulin-dependent kinase activity. The assay was done in the presence $(+)$ and absence $(-)$ of TFP. Samples ( $4 \mu \mathrm{g}$ protein in $50 \mu \mathrm{l})$ were applied to SDSPAGE ( $8 \%$ resolving gel) and the phosphoproteins were visualized by autoradiography (exposure time, $2 \mathrm{hr}$ ) Symbols depict autophosphorylated subunits of putative CaM kinase II ( $\alpha$ $=50 \mathrm{kDa}$ subunit and $\beta_{1} \beta_{2}=58-60$ $\mathrm{kDa}$ subunit). The following molecular-weight standards were used: carbonic anhydrase, $29 \mathrm{kDa}$; egg albumin $45 \mathrm{kDa}$; bovine albumin, $66 \mathrm{kDa}$; rabbit muscle phosphorylase b, $97.4 \mathrm{kDa}$; $E$. coli $\beta$ galactosidase, $116 \mathrm{kDa}$; rabbit muscle myosin, $205 \mathrm{kDa}$.

\section{AUTORADIOGRAM}

\section{El 150350 Std}

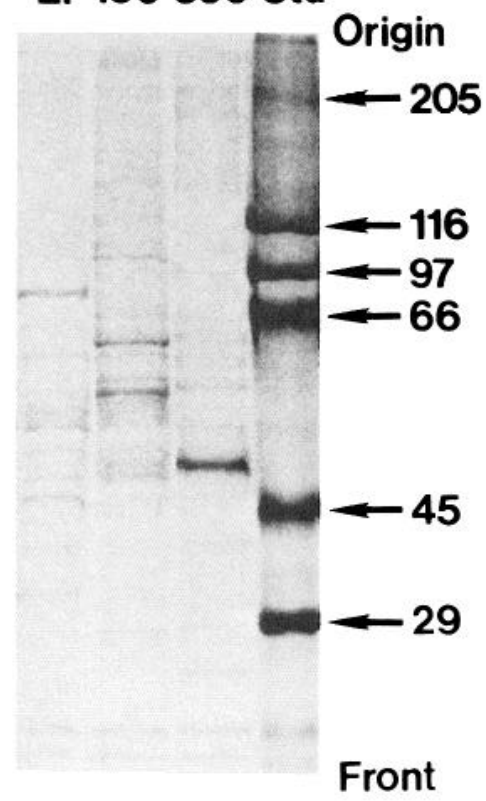

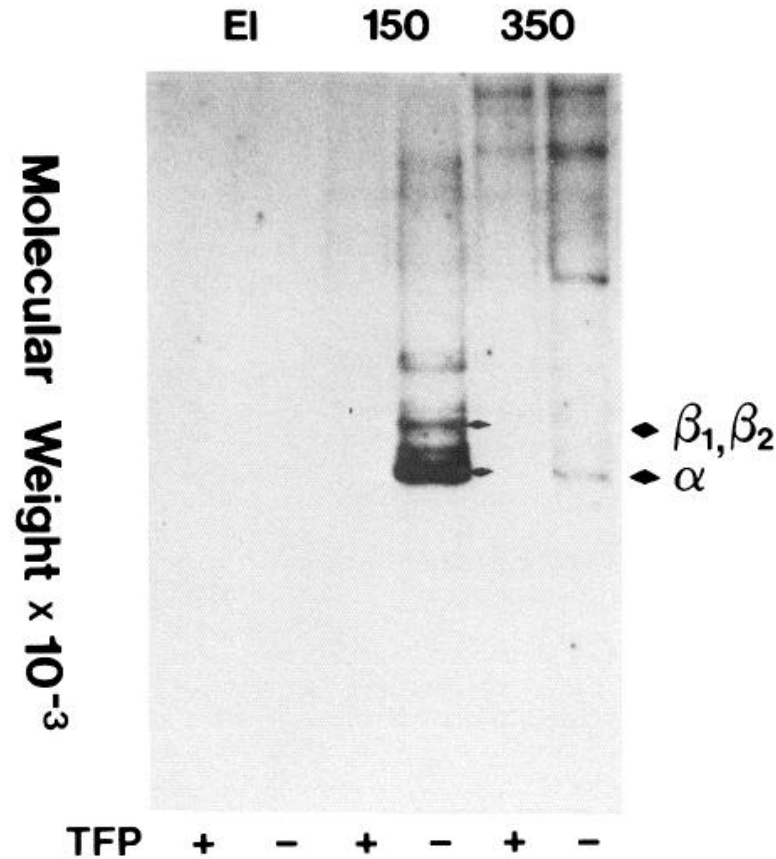

recovered in the 150 fractions, representing an enrichment of 7 - to 15 -fold.

Figure 2 compares the endogenous calcium/calmodulin-dependent phosphorylation of proteins from the 3 major peaks obtained during S-Sepharose chromatography with their corresponding protein profiles. The eluate fractions contained minimal calmodulin-dependent kinase activity. The 150 fractions contained a calmodulin-dependent kinase activity that phosphorylated several endogenous proteins, including major phosphoproteins of 50 and $58-60 \mathrm{kDa}$, presumably corresponding to the autophosphorylated subunits of CaM kinase II. A minor peak of calmodulin-dependent kinase activity was also present in the 350 fractions, which may represent an isozyme of $\mathrm{CaM}$ kinase II containing a greater ratio of $58-60 \mathrm{kDa} / 50 \mathrm{kDa}$ subunit, as observed previously when similar separation conditions were used to purify $\mathrm{CaM}$ kinase II from mouse brain cytosol (Vallano, 1988).

Calmodulin-affinity chromatography. A distinctive feature of CaM kinase II from rat brain is the presence of 2 calmodulinbinding subunits that bind to calmodulin-affinity resin in a calcium-dependent manner. To further purify the putative $\mathrm{CaM}$ kinase II from NG108 cells, the peak fractions from the

Table 1. Purification of MAP-2 kinase

\begin{tabular}{lccccc} 
& $\begin{array}{l}\text { Total } \\
\text { protein } \\
(\mathrm{mg})\end{array}$ & $\begin{array}{l}\text { Specific } \\
\text { activity } \\
(\mathrm{nmol} / \\
\mathrm{min} / \mathrm{mg})\end{array}$ & $\begin{array}{l}\text { Total } \\
\text { activity } \\
(\mathrm{nmol} /\end{array}$ & $\begin{array}{l}\text { Yield } \\
\text { (\%) }\end{array}$ & $\begin{array}{l}\text { Purifi- } \\
\text { cation } \\
\text { (Fold) }\end{array}$ \\
\hline Fraction & 357 & 0.123 & 43.911 & 100 & 1 \\
Homogenate & 147 & 0.205 & 30.135 & 69 & 1.7 \\
$\begin{array}{l}100,000 \times g \text { Supernate } \\
\text { Calmodulin-Sepharose 150 fraction }\end{array}$ & 9 & 1.400 & 12.600 & 29 & 11 \\
& 0.2 & 37.625 & 7.149 & 16 & 306 \\
\hline
\end{tabular}

S-Sepharose column that contained the majority of recovered kinase activity were pooled and applied to calmodulin-affinity resin (Fig. 3). The majority of applied protein appeared in the column eluate (solid lines) and contained minimal calmodulindependent kinase activity. The majority of recovered calmodulin-dependent kinase activity eluted as a sharp peak when calcium in the column buffer was replaced with buffer containing 2 mм EGTA (dashed lines). Typically, $18-24 \%$ of the calcium/ calmodulin-dependent kinase activity in cytosol was recovered in this peak, representing an enzyme enrichment of approximately 200 -fold over cytosol and a specific activity of 37.6 $\mathrm{nmol} / \mathrm{mg} / \mathrm{min}$ (Table 1). The specific activity of the calmodulindependent kinase for MAP-2 substrate was similar to rat brain kinase using the same assay procedure (e.g., NG108 cell homogenate $=0.123 \mathrm{nmol} / \mathrm{mg} / \mathrm{min}$ vs. rat brain homogenate $=$ $0.145 \mathrm{nmol} / \mathrm{mg} / \mathrm{min}$ ). It should be noted that widely divergent activities $(27.6-1015 \mathrm{nmol} / \mathrm{mg} / \mathrm{min})$ for purified rat brain CaM kinase II have been reported using MAP-2 substrate (Yamauchi and Fujisawa, 1982; Bennett et al., 1983; Schulman, 1984; McGuinness et al., 1985; Schulman et al., 1985). Possible reasons for disparate values are different phosphorylation assay conditions, degrees of enzyme purification, and MAP-2 preparations, indicating a need to standardize certain parameters to aid in comparing data from different laboratories.

Sephacryl S-300 chromatography. The peak fractions from the calmodulin-affinity column containing the majority of recovered kinase activity were pooled, concentrated, and applied to gel-filtration chromatography on a calibrated column of Sephacryl S- 300 superfine in order to further purify the kinase activity and to estimate the molecular weight of the holoenzyme. Elution of the holoenzyme was monitored by silver-staining of the predominant $50 \mathrm{kDa}$ kinase subunit on SDS-PAGE and by assaying for the presence of a major $50 \mathrm{kDa}$ and minor $58-60 \mathrm{kDa}$ phosphoprotein that demonstrated calmodulin-dependent autophosphorylation (data not shown). Because of the relatively 


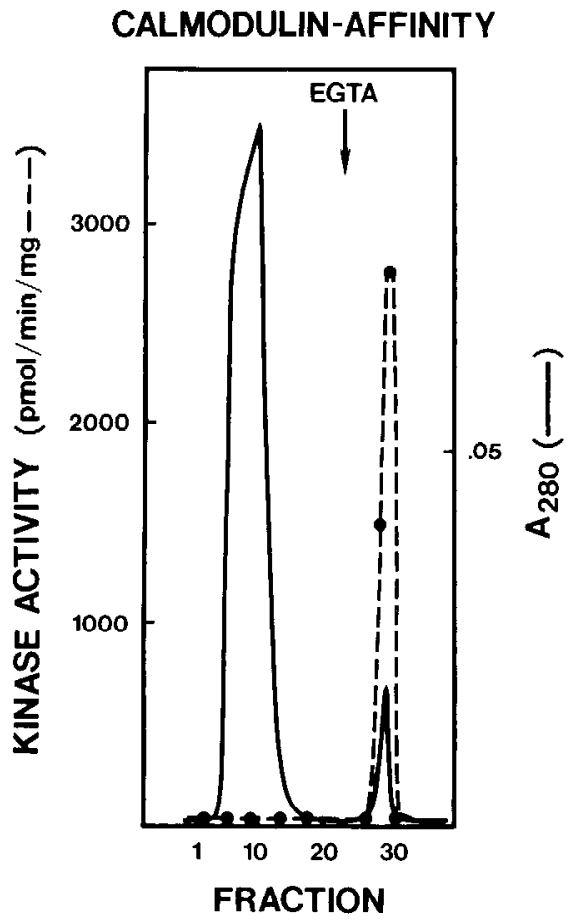

Figure 3. Calmodulin-affinity elution profile of calcium/calmodulindependent kinase activity. The peak fractions (\#16-19) from the S-Sepharose column were pooled and applied to calmodulin-affinity resin (see Materials and Methods). Protein absorbance ( - ) and kinase activity $(---)$ were quantitated as described in Figure 1 and Materials and Methods.

low amount of applied protein $(0.19 \mathrm{mg})$, measurement of kinase activity and recovery after gel filtration chromatography was not possible and is therefore excluded from Table 1 . However, an additional 2- to 3 -fold purification is typically obtained using identical purification conditions for CaM kinase II from rat brain. A selectivity curve depicting the $K_{\mathrm{av}}$ of standard proteins and CaM kinase II is shown in Figure 4. The apparent molecular weight of the holoenzyme from 4 different preparations separated on this column was approximately $560 \mathrm{kDa}$, which is consistent with previous reports using CaM kinase II purified from rat brain where a range of 500-730 kDa has been observed.

\section{Characterization of kinase activity}

Subunit composition and properties. After gel-filtration chromatography, the purified calmodulin-dependent kinase from NG108 cells was resolved by SDS-PAGE on a mini-gel and stained for protein using silver reagent (Merril et al., 1981). Figure $5 A$ demonstrates that the enzyme contains a major 50 $\mathrm{kDa}$ and a minor 58-60 kDa subunit.

The calmodulin-affinity-purified kinase was incubated in the standard phosphorylation assay in the presence or absence of $\mathrm{Mg}^{2+}, \mathrm{Ca}^{2+}$, and calmodulin. The protein was subsequently resolved by SDS-PAGE and endogenous phosphoproteins were visualized by autoradiography. The autoradiogram shown in Figure $5 B$ demonstrates that the kinase contains a major protein of $50 \mathrm{kDa}$ and a minor protein of $58-60 \mathrm{kDa}$ that are phosphorylated in a calcium/calmodulin-dependent manner.

The calmodulin-affinity-purified kinase preparation was also examined for calcium-dependent binding of ${ }^{125}$ I-calmodulin to

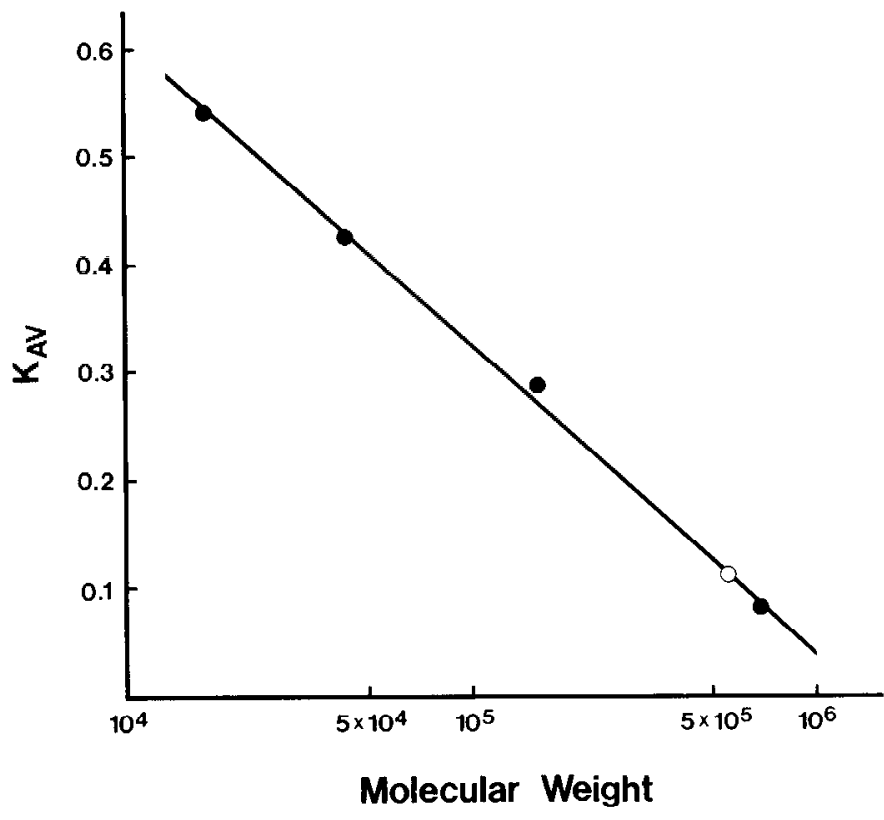

Figure 4. Selectivity curve for CaM kinase II. A calibrated column of Sephacryl S-300 superfine was used to determine the molecular weight of the holoenzyme purified from NG108 cells. The molecular-weight standards (closed circles: bovine thyroglobulin, $670 \mathrm{kDa}$; bovine gamma globulin, $158 \mathrm{kDa}$; chicken ovalbumin, $44 \mathrm{kDa}$; horse myoglobin, 17 $\mathrm{kDa}$ ) were chromatographed and plotted against the fraction of stationary gel volume, which is a vailable for diffusion of the solute $\left(K_{\mathrm{av}}\right)$. Next, the peak fractions (\#27-29) from the calmodulin-affinity chromatography step were concentrated to a volume of $1 \mathrm{ml}$ and applied to the column. The $K_{a v}$ was calculated and corresponded to a molecular weight of $560,000 \mathrm{Da}$ (open circle).

each subunit. The autoradiogram shown in Figure $5 C$ indicates that the kinase preparation contains a major $50 \mathrm{kDa}$ and a minor 58-60 $\mathrm{kDa}$ subunit. When the equilibration buffer used to wash the blotting membrane contained $2 \mathrm{~mm}$ EGTA instead of $2 \mathrm{~mm}$ calcium, ${ }^{125} \mathrm{I}$-calmodulin did not bind to either subunit, indicating that the binding is calcium-dependent. Also shown in Figure $5 \mathrm{C}$ is the specific binding of ${ }^{125} \mathrm{I}$-calmodulin to the 50 $\mathrm{kDa}$ and $58-60 \mathrm{kDa}$ subunits of CaM kinase II purified from rat brain cytosol.

Based upon protein-staining pattern, calmodulin-binding protein pattern, and subunit autophosphorylation pattern, a greater ratio of $50 \mathrm{kDa} / 58-60 \mathrm{kDa}$ subunit is present in CaM kinase II from NG108 cells compared with CaM kinase II from rat cerebrum. These data suggest that the kinase in NG108 cells is an isozyme of CaM kinase II containing a greater proportion of 50 $\mathrm{kDa}$ subunits relative to 58-60 kDa subunits. Previous studies performed in different brain regions (Walaas et al., 1983; Erondu and Kennedy, 1985), pancreas (Gorelick et al., 1983), liver (Payne et al., 1983), and squid optic lobe and stellate ganglion (Llinás et al., 1985) suggest that isozymes of CaM kinase II containing predominantly $50 \mathrm{kDa}$ subunit or variable proportions of both subunits are present in these tissues.

Substrate specificity. CaM kinase II can be distinguished from other calmodulin-dependent protein kinases also present in nervous tissue based upon its broad substrate specificity. The specificity of the calmodulin-affinity-purified CaM kinase II from NG108 cells was tested using different exogenous substrates and a calmodulin-affinity-purified preparation. MAP-2 was the best substrate tested. The relative rate of phosphate incorporation 


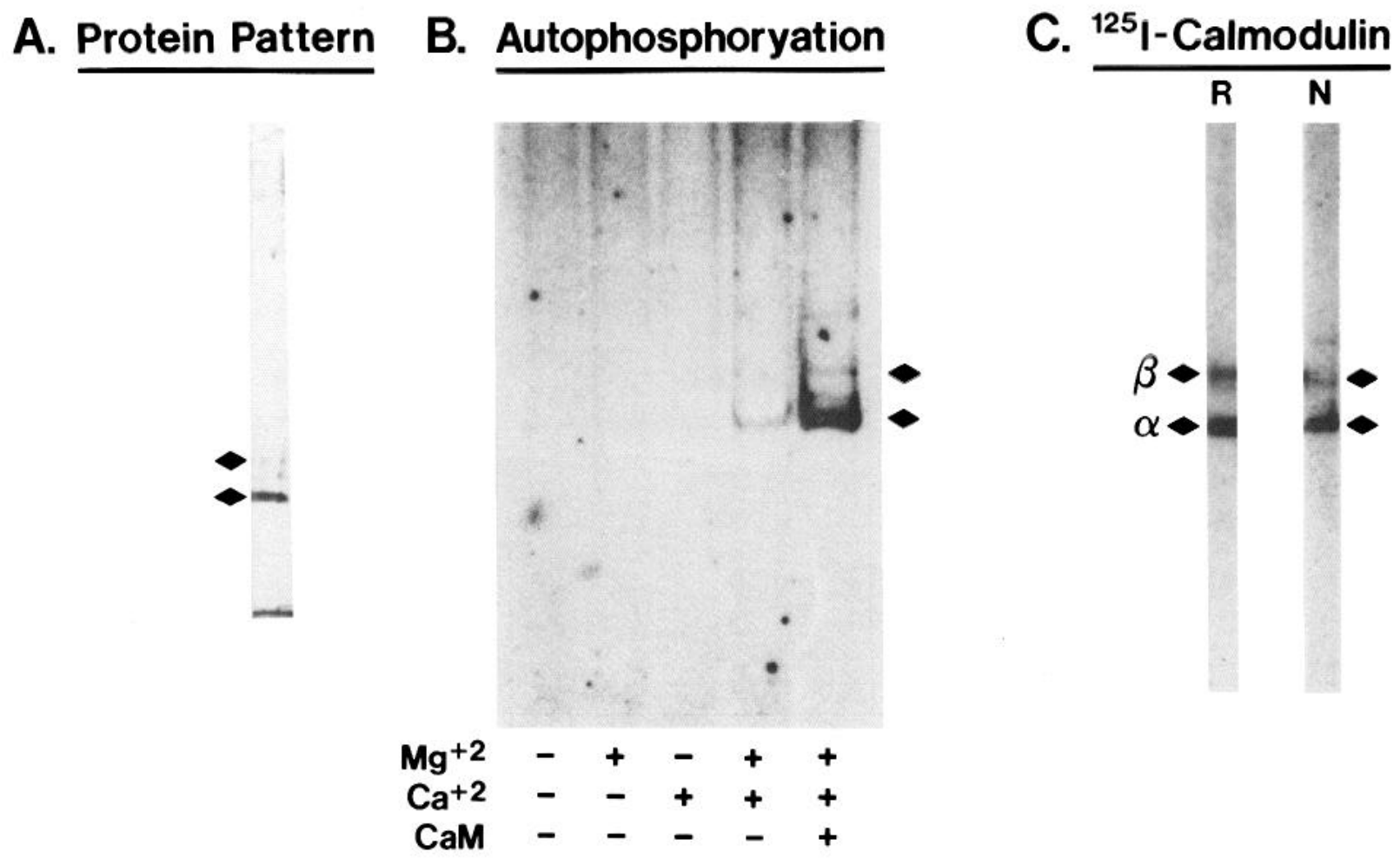

Figure 5. Protein staining, endogenous calcium/calmodulin-dependent autophosphorylation, and ${ }^{125}$ I-calmodulin-binding to NG108 enzyme. $A$, Kinase preparation obtained after gel-filtration chromatography was resolved on SDS-PAGE using a minigel system ( $8 \%$ resolving gel) and analyzed for protein by silver staining. Symbols depict the positions of the 50 and $58-60 \mathrm{kDa}$ subunits of CaM kinase II as determined by comigration analysis with CaM kinase II from rat brain. $B$, Kinase preparation obtained after calmodulin-affinity chromatography was phosphorylated in the standard phosphorylation assay in the presence (+) and absence $(-)$ of $\mathrm{Mg}^{2+}, \mathrm{Ca}^{2+}$, and calmodulin $(\mathrm{CaM})$. The phosphoproteins were resolved by SDS-PAGE ( $8 \%$ resolving gel) followed by autoradiography. Symbols depict the 50 and $58-60 \mathrm{kDa}$ subunits of the kinase. $C$, Kinase preparations from rat $(R)$ and NG108 cells $(N)$ were resolved on SDS-PAGE ( $8 \%$ resolving gel) and protein was electrophoretically transferred to Zeta-Probe blotting membrane. The blotting membrane was analyzed for ${ }^{125} \mathrm{I}$-calmodulin-binding proteins by autoradiography (exposure time, $48 \mathrm{hr}$ ). $\alpha$ and $\beta$ depict the 50 and $58-60 \mathrm{kDa}$ CaM kinase subunits, respectively.

into tubulin and histone was 4 and $3 \%$, respectively, compared with MAP-2. The enzyme did not phosphorylate either phosphorylase b or casein (results not shown). The substrate specificity thus determined is comparable to CaM kinase II purified from rat brain (Goldenring et al., 1983; Bennett et al., 1983).

Time course, ATP and calmodulin-dependence. Under standard phosphorylation conditions, the time course for phosphorylation of exogenous MAP-2 substrate or autophosphorylation of the $50 \mathrm{kDa}$ subunit was linear up to $1.5 \mathrm{~min}$ and reached a plateau by $10-15 \mathrm{~min}$ at $30^{\circ} \mathrm{C}$. The apparent $k_{m}$ 's for ATP and calmodulin were $3 \mu \mathrm{M}$ and $38 \mathrm{~nm}$, respectively (results not shown).

Phosphopeptide maps. As a final criterion for identifying the putative CaM kinase II in NG108 cells, 1-dimensional phosphopeptide maps derived from partial proteolysis of the autophosphorylated subunits of purified CaM kinase II from rat brain and NG108 cells were compared. Figure 6 demonstrates that the maps of $50 \mathrm{kDa}$ subunits from both sources are similar and contain major phosphopeptides of $8.3,11.5,13$, and 15 $\mathrm{kDa}$. The maps of 58-60 kDa subunits from NG108 and rat are also similar and contain major phosphopeptides of 15.5 and 20-22 kDa. Homologous but nonidentical phosphopeptide maps were obtained when the autophosphorylated $50 \mathrm{kDa}$ subunit from rat brain was compared to a calcium/calmodulin-dependent kinase from pheochromocytoma (PC12) cells (Nose et al., 1985). Whether this distinction reflects the presence of different isozymes of CaM kinase II in the rat, NG108, and PC12 prep- arations, or different phosphorylated states of the endogenous enzymes in these preparations remains to be determined.

Effect of cell differentiation on CaM kinase II activity. A primary objective of characterizing CaM kinase II in NG108 cells was to determine the utility of this cell system in elucidating the role of CaM kinase II in neuronal function. Since differentiated NG108 cells demonstrate stronger or unique expression of several neuronal properties of which CaM kinase II is a proposed regulator, we predicted that the amount and/or activity of CaM kinase II would be increased in differentiated cells compared with control cells. In a series of experiments, NG108 cells were treated with $1 \mathrm{mM}$ dibutyryl cAMP for 6-9 d. Control and treated cells were harvested, and whole-cell homogenates were assayed for CaM kinase II activity with the standard phosphorylation system. In 12 separate experiments, both the endogenous and MAP-2 calcium/calmodulin-dependent kinase activity per $\mathrm{mg}$ protein was increased by 2 - to 4 -fold in differentiated cell homogenates compared with control cells. A representative experiment is depicted in Figure $7 A$. The major endogenous phosphoproteins ranged from 50 to $130 \mathrm{kDa}$, including phosphoproteins corresponding to the autophosphorylated subunits of CaM kinase II. These studies indicate that the activity and/or amount of CaM kinase II is greater in differentiated cells compared with control cells.

To determine whether the amount of CaM kinase II was greater in differentiated cells, whole-cell homogenates from con- 
trol and differentiated cells were assayed for ${ }^{125} \mathrm{I}$-calmodulinbinding proteins. Figure $7 B$ shows that both control and treated cell homogenates contain a major $50 \mathrm{kDa}$ and a minor 58-60 $\mathrm{kDa}$ calmodulin-binding protein. These proteins comigrate with CaM kinase II purified from rat brain cytosol and NG108 cells. The amount of ${ }^{125} \mathrm{I}$-calmodulin-binding to the kinase subunits was significantly greater in homogenates from differentiated cells compared with control cells as determined by densitometric analysis. These data suggest that there may be an increase in $\mathrm{CaM}$ kinase II expression during cellular differentiation, although further studies are required to resolve this issue.

\section{Discussion}

The NG108 cell line has proven extremely useful in investigating the molecular mechanisms of cellular signal transduction for several neurohormones and pharmacological agents (for reviews, see Hamprecht, 1977; Nirenberg et al., 1983; Hamprecht et al., 1985). Under specific conditions of culture, cells undergo a differentiation process and display a variety of neuronal-like properties characterized by development of electrical excitability, elaboration of long cytoskeletal-filled neurites, and synapse formation. Based upon evidence that CaM kinase II may regulate synaptic and cytoskeletal dynamics, our working hypothesis was that the kinase activity would be induced during cellular differentiation. Since information regarding the presence of CaM kinase II in these cells was lacking, our first goal was to identify and characterize the calcium/calmodulin-dependent kinase activity in NG108 cells.

Using a combination of centrifugation and column chromatographic techniques, a calcium/calmodulin-dependent protein kinase was purified approximately 200 -fold from NG108 cell cytosol. This kinase is homologous to CaM kinase II from rat brain based upon all of the biochemical criteria examined. A distinctive difference between the 2 kinases is the higher molar ratio of $50 \mathrm{kDa}$ subunit relative to $58-60 \mathrm{kDa}$ subunit in NG108 cells, indicating that an isozyme of CaM kinase II is predominant in NG108 cells.

Our second goal was to initiate studies comparing the activity and amount of the kinase in control versus differentiated cells. Studies examining the activity of CaM kinase II in whole-cell homogenates demonstrated a 2- to 4-fold increase in differentiated cells. The observed increase in activity may reflect an increase in the absolute amount of CaM kinase II due to increased transcription or translation; an increase in the activity of CaM kinase II due to modification of the enzyme itself such as the state of enzyme autophosphorylation; an effect on another enzyme system that modifies CaM kinase II activity such as stimulation of calcineurin, a calmodulin-dependent phosphatase; or some combination of these processes.

To determine whether differentiated cells contain a greater amount of CaM kinase II, the amount of ${ }^{125}$ I-calmodulin-binding to CaM kinase II subunits derived from control versus differentiated cell homogenates was measured. Based upon densitometric analysis, a significant increase in calmodulin-binding per $\mathrm{mg}$ protein was observed in differentiated cells. These observations suggest that CaM kinase II expression is increased during differentiation, although potential contributions of additional factors that alter enzyme activity should also be considered.

In a study examining the effect of calcium-dependent phosphorylation on tyrosine hydroxylase activity in PC1 2 cells, Nose et al. (1985) reported an $80-100 \%$ increase in a calcium/cal-

\section{PHOSPHOPEPTIDES}

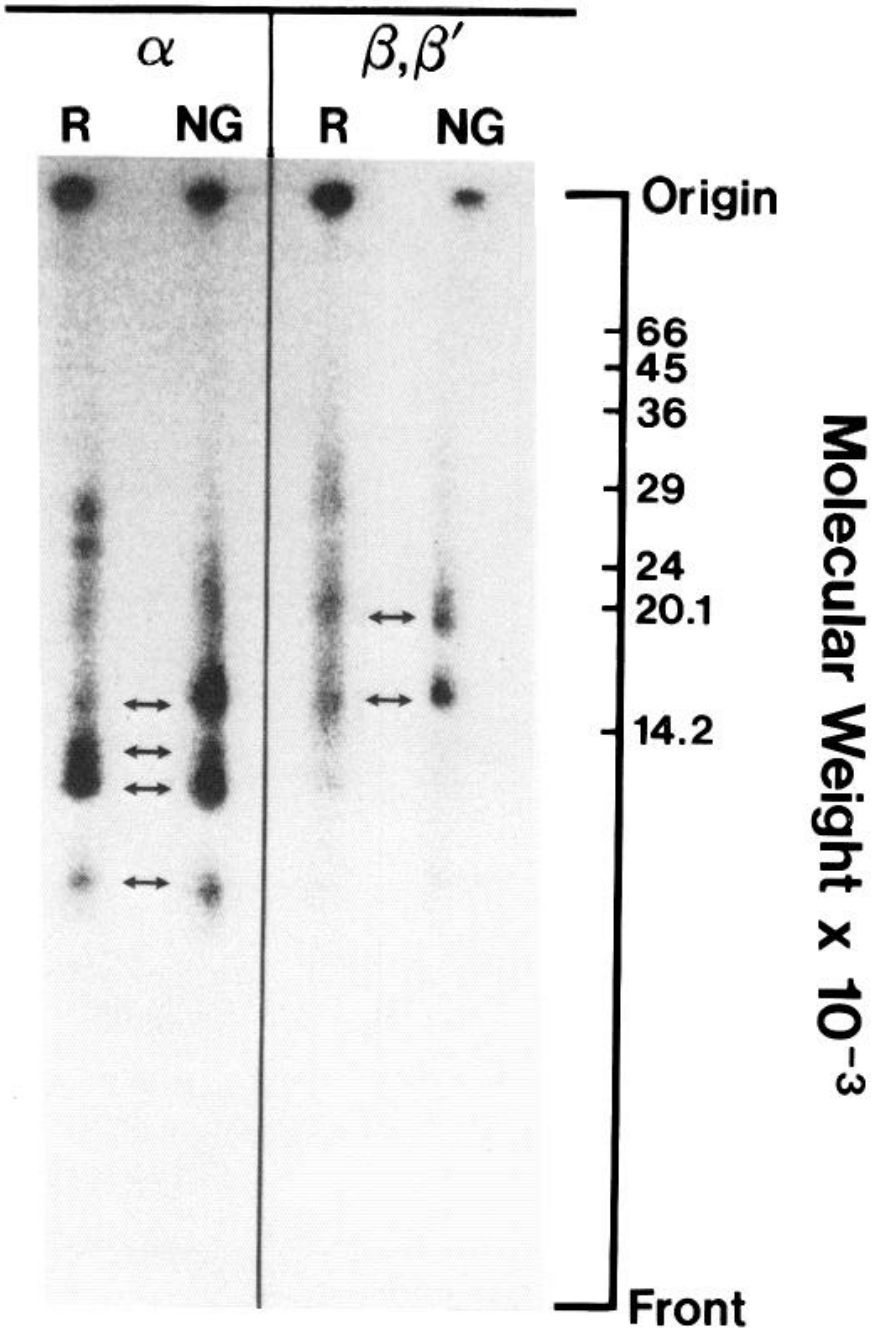

Figure 6. Comparison of 1-dimensional phosphopeptide maps of the 50 and $58-60 \mathrm{kDa}$ kinase subunits from NG108 cells and rat brain. The autophosphorylated subunits of purified kinase from NG108 cells $(N G)$ and rat $(R)$ were resolved on SDS-PAGE ( $8 \%$ resolving gel), excised from the gel, and subjected to limited proteolysis for $2 \mathrm{hr}$ in a second gel using $10 \mu \mathrm{g}$ of $S$. aureus V8 protease followed by SDS-PAGE $(15 \%$ resolving gel). The phosphopeptides were visualized by autoradiography (exposure time, $24 \mathrm{hr}$ for NG $\beta, \beta^{\prime}$ and $7 \mathrm{hr}$ for the other lanes). $\alpha=50$ $\mathrm{kDa}$ subunit of CaM kinase; $\beta=58-60 \mathrm{kDa}$ subunit of CaM kinase. Arrows depict the positions of the major phosphopeptides.

modulin-dependent MAP-2 kinase activity/mg protein in extracts from cells treated with nerve growth factor (NGF) for 57 d compared with control cells. Although the MAP-2 kinase activity was not purified and the nature of the NGF effect was not explored further, another laboratory failed to observe a shortterm effect of NGF on CaM kinase II activity in PC12 cells (Nairn et al., 1987), suggesting that the apparent increase in calmodulin-dependent kinase activity observed by Nose et al. (1985) was due to chronic treatment of PC12 cells with NGF. Interestingly, long-term treatment of PC12 cells with NGF also induces expression of synapsin I (Romano et al., 1987), a synaptic vesicle-associated protein that appears to be a physiological substrate of $\mathrm{CaM}$ kinase II and plays a role in synaptic neurotransmission (Llinás et al., 1985). Moreover, differentiation of both PC1 2 cells (Greene and Tischler, 1982) and NG108 
Figure 7. Comparison of endogenous CaM kinase II activity and calmodulinbinding proteins in control versus differentiated cells. $A$, Whole-cell homogenates were prepared from differentiated or control cells, and equal amounts of protein were phosphorylated in the standard assay in the presence $(+)$ and absence $(-)$ of TFP. Samples $(5 \mu \mathrm{g} / 50 \mu \mathrm{l})$ were subsequently resolved on SDS-PAGE (7\% resolving gel) and phosphoproteins were visualized by autoradiography (exposure time, $10 \mathrm{hr})$. Symbols depict $50 \mathrm{kDa}(\alpha)$ and $58-60 \mathrm{kDa}(\beta)$ subunits of $\mathrm{CaM}$ kinase II. $B$, Whole-cell homogenates were prepared from control $(C)$ and differentiated $(D)$ cells, and equal amounts of protein $(50 \mu \mathrm{g})$ were resolved on SDSPAGE ( $8 \%$ resolving gel), followed by electrophoretic transfer to Zeta-Probe blotting membrane. The preparations were subsequently analyzed for ${ }^{125} \mathrm{I}$-calmodulin-binding proteins by autoradiography. Symbols depict $50 \mathrm{kDa}(\alpha)$ and $58-60 \mathrm{kDa}(\beta)$ subunits of $\mathrm{CaM}$ kinase II.
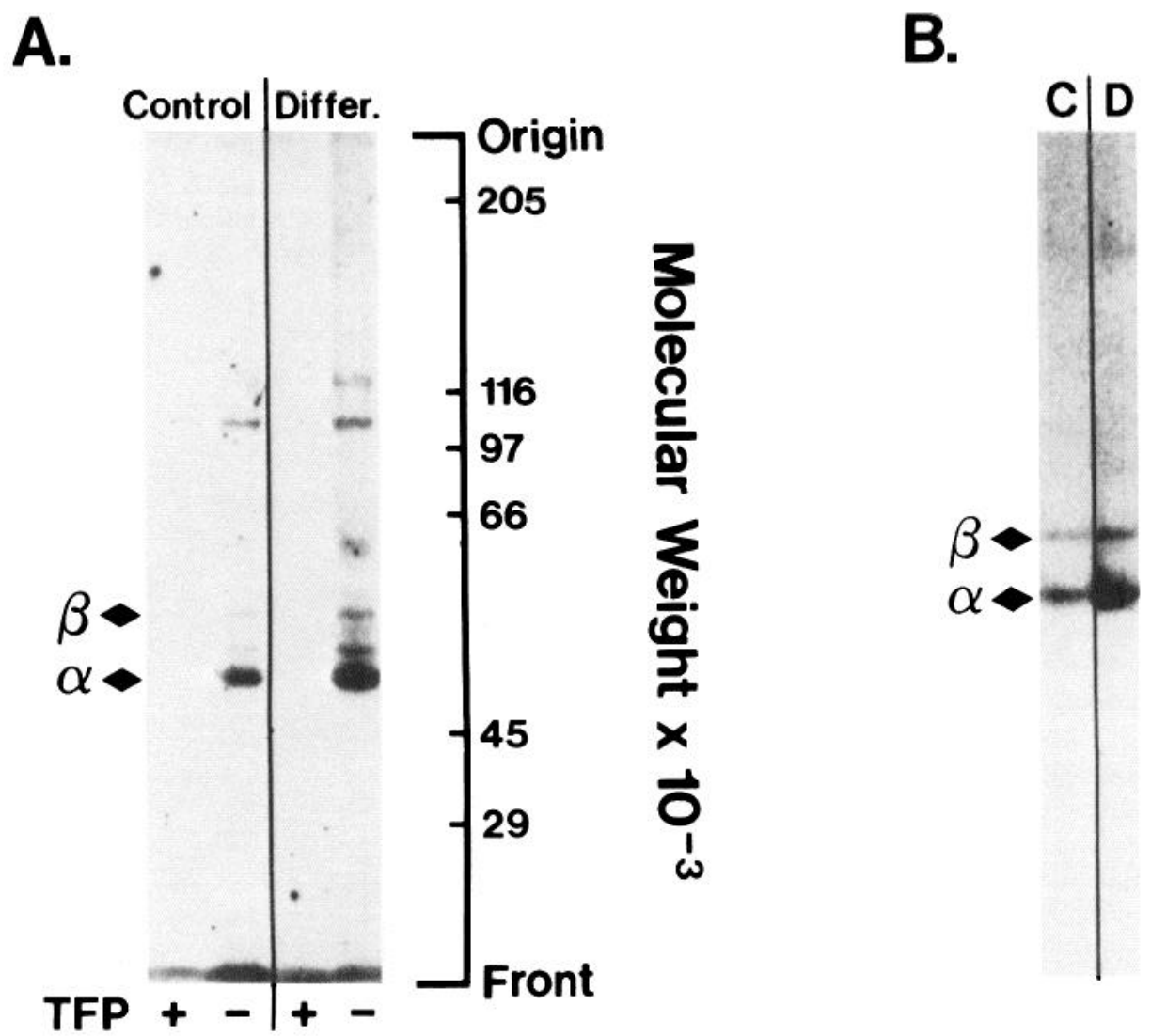

cells (Nirenberg et al., 1983) is characterized by development of electrical excitability due in part to induction of voltagesensitive calcium channels. Thus, the observed increase in CaM kinase II with differentiation may add a crucial component to the repertoire of biochemical machinery that the cell requires for a rapid and sensitive response to cell-surface active ligands that use calcium as a second messenger in signal transduction.

\section{References}

Amano, T., B. Hamprecht, and W. Kemper (1974) High activity of choline acetyltransferase induced in neuroblastoma $\times$ glia hybrid cells. Exp. Cell Res. 85: 399-408.

Bennett, M. K., and M. B. Kennedy (1987) Deduced primary structure of the $\beta$ subunit of brain type II $\mathrm{Ca}^{2+} /$ calmodulin-dependent protein kinase determined by molecular cloning. Proc. Natl. Acad. Sci. USA 84: 1794-1798.

Bennett, M. K., N. E. Erondu, and M. B. Kennedy (1983) Purification and characterization of a calmodulin-dependent protein kinase that is highly concentrated in brain. J. Biol. Chem. 258: 12735-12744.

Bradford, M. M. (1976) A rapid and sensitive method for the quantitation of microgram quantities of protein utilizing the principle of protein-dye binding. Anal. Biochem. 72: 248-254.

Carlin, R. K., D. J. Grab, and P. Siekevitz (1981) Function of calmodulin in postsynaptic densities. III. Calmodulin-binding proteins of the postsynaptic density. J. Cell Biol. 89: 449-455.

Charness, M. E., L. A. Querimit, and I. Diamond (1986) Ethanol increases the expression of functional delta-opioid receptors in neuroblastoma $\times$ glioma NG108-15 hybrid cells. J. Biol. Chem. 261: 3164-3169.

Cleveland, D. W., S. G. Fischer, M. W. Kirschner, and U. K. Laemmli (1977) Peptide mapping by limited proteolysis in sodium dodecyl sulfate and analysis by gel electrophoresis. J. Biol. Chem. 252: 11021106.

Erondu, N. E., and M. B. Kennedy (1985) Regional distribution of type II $\mathrm{Ca}^{2+} /$ calmodulin-dependent protein kinase in rat brain. J. Neurosci. 5: 3270-3277.
Fellous, A., J. Francon, A. Lennon, and J. Nunez (1977) Microtubule assembly in vitro: Purification of assembly-promoting factors. Eur. J. Biochem. 78: 167-174.

Fukunaga, K., H. Yamamoto, K. Matsui, K. Higashi, and E. Miyamoto (1982) Purification and characterization of a Ca ${ }^{2+}$ - and calmodulindependent protein kinase from rat brain. J. Neurochem. 39: 16071617.

Goldenring, J. R., B. Gonzalez, J. S. McGuire, Jr., and R. J. DeLorenzo (1983) Purification and characterization of a calmodulin-dependent kinase from rat brain cytosol able to phosphorylate tubulin and microtubule-associated proteins. J. Biol. Chem. 258: 12632-12640.

Goldenring, J. R., J. S. McGuire, Jr., and R. J. DeLorenzo (1984) Identification of the major postsynaptic density protein as homologous with the major calmodulin-binding subunit of a calmodulindependent protein kinase. J. Neurochem. 42: 1077-1084.

Goldenring, J. R., M. L. Vallano, R. S. Lasher, T. Ueda, and R. J. DeLorenzo (1986) Association of calmodulin-dependent kinase II and its substrate proteins with neuronal cytoskeleton. Prog. Brain Res. 69: 341-354.

Gorelick, F. S., J. A. Cohn, S. D. Freedman, N. G. Delahunt, J. M. Gershoni, and J. D. Jamieson (1983) Calmodulin-stimulated protein kinase activity from rat pancreas. J. Cell Biol. 97: 1294-1298.

Grab, D. J., R. K. Carlin, and P. Siekevitz (1981) Function of calmodulin in postsynaptic densities. II. Presence of calmodulin-activatable protein kinase activity. J. Cell Biol. 89: 440-448.

Greene, L. A., and A. S. Tischler (1982) PC12 pheochromocytoma cultures in neurobiological research. Adv. Cell Neurobiol. 3: 373414.

Guldner, F. A., and C. A. Ingham (1979) Plasticity in synaptic appositions of optic nerve afferents under different lighting conditions. Neurosci. Lett. 14: 235-240.

Hamprecht, B. (1977) Structural, electrophysiological, biochemical, and pharmacological properties of neuroblastoma-glioma cell hybrids in cell culture. Int. Rev. Cytol. 49: 99-170.

Hamprecht, B., T. Glaser, G. Reiser, E. Bayer, and F. Propst (1985) Culture and characteristics of hormone-responsive neuroblastoma $\times$ glioma hybrid cells. Methods Enzymol. 109: 316-341.

Hanley, R. M., A. R. Means, T. Ono, B. E. Kemp, K. E. Burgin, N. 
Waxham, and P. T. Kelly (1987) Functional analysis of a complementary DNA for the 50-Kilodalton subunit of calmodulin kinase II. Science 237: 293-297.

Higashida, H., and D. A. Brown (1986) Two polyphosphatidylinositide metabolites control two $\mathrm{K}^{+}$currents in a neuronal cell. Nature 323: 333-335

Kaltenbach, J. P., M. H. Kaltenbach, and W. B. Lyons (1958) Nigrosin as a dye for differentiating live and dead ascites cells. Exp. Cell Res. 15: 112-117.

Kelly, P. T., T. L. McGuiness, and P. Greengard (1984) Evidence that the major postsynaptic density protein is a component of a $\mathrm{Ca}^{2+}$ calmodulin-dependent protein kinase. Proc. Natl. Acad. Sci. USA 81 : 945-949.

Kennedy, M. B., M. K. Bennett, and N. E. Erondu (1983) Biochemical and immunochemical evidence that the "major postsynaptic density protein" is a subunit of a calmodulin-dependent protein kinase. Proc. Nat1. Acad. Sci. USA 80: 7357-7361.

Laemmli, U. K. (1970) Cleavage of structural proteins during the assembly of the head bacteriophage T4. Nature 227:680-685.

Lai, Y., A. C. Nairn, and P. Greengard (1986) Autophosphorylation reversibly regulates the $\mathrm{Ca}^{2+} /$ calmodulin-dependence of $\mathrm{Ca}^{2+} / \mathrm{cal}-$ modulin-dependent protein kinase II. Proc. Natl. Acad. Sci. USA 83: 4253-4257.

Lin, C. R., M. S. Kapiloff, S. Durgerian, K. Tatemoto, A. F. Russo, P. Hanson, H. Schulman, and M. G. Rosenfeld (1987) Molecular cloning of a brain-specific calcium/calmodulin-dependent protein kinase. Proc. Natl. Acad. Sci. USA 84: 5962-5966.

Llinás, R., T. L. McGuinness, C. S. Leonard, M. Sugimori, and P. Greengard (1985) Intradermal injections of synapsin I or calcium/ calmodulin-dependent protein kinase II alters neurotransmitter release at the squid giant synapse. Proc. Natl. Acad. Sci. USA 82: 30353039.

Marshak, D. R., D. M. Watterson, and L. J. Van Eldik (1981) Calciumdependent interaction of $S 100 \mathrm{~b}$, troponin $\mathrm{C}$, and calmodulin with an immobilized phenothiazine. Proc. Natl. Acad. Sci. USA 78: 67936797.

McGuinness, T. L., Y. Lai, P. Greengard, J. R. Woodgett, and P. Cohen (1983) A multifunctional calmodulin-dependent protein kinase. Similarities between skeletal muscle glycogen synthase kinase and a brain synapsin I kinasc. FEBS Lett. 163: 329-334.

McGuinness, T. L., Y. Lai, and P. Greengard (1985) $\mathrm{Ca}^{2+} /$ calmodulin- $^{2}$ dependent protein kinase II. Isozymic forms from rat forebrain and cerebellum. J. Biol. Chem. 260: 1696-1704.

Merril, C. R., D. Goldman, S. A. Sedman, and M. H. Ebert (1981) Ultrasensitive stain for proteins in polyacrylamide gels shows regional variation in cerebrospinal fluid protein. Science 211: 1437-1438.

Miller, S. G., and M. B. Kennedy (1986) Regulation of brain type II $\mathrm{Ca}^{2+} /$ calmodulin-dependent protein kinase by autophosphorylation: A Ca ${ }^{2+}$-triggered molecular switch. Cell 44: 861-870.

Minna, J., D. Glazer, and M. Nirenberg (1972) Genetic dissection of neural properties using somatic cell hybrids. Nature [New Biol.] 235: 225-231.

Nairn, A. C., H. C. Hemmings, and P. Greengard (1985) Protein kinascs in the brain. Annu. Rcv. Biochem. 54: 931-976.

Nairn, A. G., R. A. Nichols, M. J. Brady, and H. C. Palfrey (1987) Nerve growth factor treatment or cAMP elevation reduces $\mathrm{Ca}^{2+} / \mathrm{cal}$ modulin-dependent protein kinase III activity in PC12 cells. J. Biol. Chem. 262: 14265-14272.

Nirenberg, M., S. Wilson, H. Higashida, A. Rotter, K. Krueger, N. Busis, R. Ray, J. G. Kenimer, and M. Adler (1983) Modulation of synapse formation by cyclic adenosine monophosphate. Science 222: 794799.

Nose, P. S., L. C. Griffith, and H. Schulman (1985) $\mathrm{Ca}^{2+}$-dependent phosphorylation of tyrosine hydroxylase in PC12 cells. J. Cell Biol. $101 \cdot 1182-1190$
Ouimet, C. C., T. L. McGuinness, and P. Greengard (1984) Immunocytochemical localization of calcium/calmodulin-dependent protein kinase II in rat brain. Proc. Natl. Acad. Sci. USA 81: 5604-5608.

Payne, M. E., C. M. Schworer, and T. R. Soderling (1983) Purification and characterization of rabbit liver glycogen synthase kinase. J. Biol Chem. 258: 2376-2382.

Peluso, R. W., and G. H. Rosenberg (1987) Quantitative electrotransfer of proteins from sodium dodecyl sulfate-polyacrylamide gels onto positively charged nylon membranes. Anal. Biochem. 162: 389-398.

Romano, C., R. A. Nichols, P. Greengard, and L. A. Greene (1987) Synapsin I in PC12 cells. I. Characterization of the phosphoprotein and effect of chronic NGF treatment. J. Neurosci. 7: 1294-1299.

Sabol, S. L., and M. Nirenberg (1979) Regulation of adenylate cyclase of neuroblastoma $\times$ glioma hybrid cells by alpha-adrenergic receptors. J. Biol. Chem. 254: 1921-1926.

Schulman, H. (1984) Phosphorylation of microtubule-associated proteins by a $\mathrm{Ca}^{2+} / \mathrm{calmodulin}$-dependent protein kinase. J. Cell Biol. 99: 11-19.

Schulman, H., J. Kuret, A. B. Jefferson, P. S. Nose, and K. H. Spitzer (1985) $\mathrm{Ca}^{2+} /$ calmodulin-dependent microtubule-associated protein 2 kinase: Broad substrate specificity and multifunctional potential in diverse tissues. Biochem. 24: 5320-5327.

Schworer, C. M., R. J. Colbran, and T. R. Soderling (1986) Reversible generation of a $\mathrm{Ca}^{2+}$-independent form of $\mathrm{Ca}^{2+}$ (calmodulin)-dependent protein kinase II by an autophosphorylation mechanism. J. Biol. Chem. 261: 8581-8584.

Shelanski, M. L., F. Gaskin, and C. R. Cantor (1973) Microtubule assembly in the absence of added nucleotides. Proc. Natl. Acad. Sci. USA 70: 765-768.

Siekevitz, P. (1985) The postsynaptic density: A possible role in longlasting effects in the central nervous system. Proc. Natl. Acad. Sci. USA 82: 3494-3498.

Vallano, M. L. (1988) Identification and regional distribution of a type II calcium/calmodulin-dependent kinase in mouse brain. Biochem. Pharmacol. 37: 2381-2388.

Vallano, M. L., and C. M. Beaman-Hall (1987) Characterization of a type II calcium/calmodulin-dependent kinase from neuroblastoma/ glioma cells. Soc. Neurosci. Abstr. 13: 1228.

Vallano, M. L., J. R. Goldenring, T. M. Buckholz, R. E. Larson, and R. J. DeLorenzo (1985) Separation of endogenous calmodulin- and cAMP-dependent kinases from microtubule preparations. Proc. Natl. Acad. Sci. USA 82: 3202-3206.

Vallano, M. L., J. R. Goldenring, and R. J. DeLorenzo (1986) Calciumand calmodulin-dependent protein kinase: Role in memory. In Neural Mechanisms of Conditioning, D. L. Alkon and C. D. Woody, eds., pp. 383-396, Plenum, New York.

Vrensen, G., and N. Cardozo (1981) Changes in size and shape of synaptic connections after visual training: An ultrastructural approach to synaptic plasticity. Brain Res. 218: 79-97.

Walaas, S. I., A. C. Nairn, and P. Greengard (1983) Regional distribution of calcium- and cyclic adenosine 3'5-monophosphate-regulated protein phosphorylation systems in mammalian brain. J. Neurosci. 3: 291-301.

Weingarten, M. D., A. H. Lockwood, S.-Y. IIwo, and M. W. Kirschner. (1975) A protein factor essential for microtubule assembly. Proc. Natl. Acad. Sci. USA 72: 1858-1862.

Yamauchi, T., and H. Fujisawa (1982) Phosphorylation of microtubule-associated protein 2 by calmodulin-dependent protein kinase (kinase II) which occurs only in the brain tissues. Biochem. Biophys. Res. Commun. 109: 975-981.

Yamauchi, T., and H. Fujisawa (1983) Purification and characterization of the brain calmodulin-dependent protein kinase (kinase II), which is involved in the activation of tryptophan 5-monooxygenase. Eur. J. Biochem. 132: 15-21. 